\title{
VChemlab: Alternatif Media Praktikum Virtual Untuk Meningkatkan Sikap Ilmiah Mahasiswa
}

\author{
Ayu Rahayu \\ Universitas Sembilanbelas November Kolaka \\ yuayurahayu19@gmail.com
}

Abstrak: Pendidikan di Era 4.0 dalam masa pandemi Covid19 mengharuskan para pendidik melakukan semua aktifitas pembelajaran secara daring termasuk kegiatan praktikum. Penelitian ini bertujuan untuk mengetahui efektifitas VChemLab sebagai alternatif media pada kegiatan praktikum secara virtual, agar sikap ilmiah mahasiswa pada materi kimia dasar dapat meningkat. Metode pada penelitian ini adalah Pre-experimental dengan desain One-Group Pretest-posttest Design. Sampel penelitan terdiri dari dua kelas yang masing-masing berjumlah 20 mahasiswa pendidikan kimia. Hasil penelitian menunjukkan bahwa nilai $\mathrm{N}$-gain kelas $\mathrm{A}$ dan $\mathrm{B}$ yaitu 0.42 yang mengalami peningkatan sikap ilmiah mahasiswa pada kategori Sedang. Sedangkan hasil dari uji t Paired-Sample kelas A dan B diperoleh nilai Sig Sig.(2-tailed) 0,00 $<\alpha(0,05)$, dapat disimpulkan bahwa $\mathrm{H}_{0}$ ditolak dan $\mathrm{H}_{1}$ diterima. Dengan demikian, dapat dinyatakan bahwa VChemLab dapat diguanakan sebagai media alternative pada kegiatan praktikum virtual mata kuliah praktikum kimia dasar lanjut yang dapat meningkatkan sikap ilmiah mahasiswa.

Kata kunci: VChemLab, Sikap Ilmiah, Kimia Dasar

\section{Pendahuluan}

Kunci mewujudkan tujuan dari Indonesia di tahun 2045 yang dikenal sebagai Indonesia emas yang besar, maju dan bermartabat adalah manusia itu sendiri. Untuk membentuk manusia yang diharapkan pada tahun 2045 salah satunya bergantung pada proses pendidikan yang terjadi. Sehingga, pendidikan merupakan hal yang menjadi kunci utama, dengan kata lain pendidikan adalah sebuah proses yang tidak dapat berhenti mengikuti perkembangan dari era satu ke era berikutnya (Djumransjah, 2004). Oleh karena itu, pendidikan selalu mengadaptasi dan mengikuti proses perkembangan era dan fase perubahan yang dihasilkan, misalnya saat ini indonesia telah memasuki era revolusi industri 4.0 yang kemudian muncul era society 5.0.

Pengaruh era society 5.0 terhadap pendidikan yaitu bisa jadi peserta didik akan diajarkan oleh robot yang telah dirancang khusus untuk menggantikan guru atau dosen yang dioperasikan dari tempat yang berbeda (Nastiti \& Abdu, 2020) sedangkan pengaruh era revolusi industri 4.0 terhadap pendidikan yaitu mengharuskan adanya penyesuaian kurikulum dimana kegiatan belajar mengajar baik dari tingkat terendah maupun tingkat tertinggi harus selalu menyesuaikan dengan situasi yang terus update dari dampak perkembangan teknologi, dimana dengan mudah sesorang dapat mengakses dunia luar hanya melalui genggam, misalnya memanfaatkan kecanggihan internet (Simarmata, 2020).

Namun, ditengah pademi covid19 yang terjadi secara tiba-tiba, menuntut semua guru atau dosen untuk memanfaatkan digitalisasi dalam kegiatan belajar mengajar yang dimana akan berdampak pada percepatan revolusi industri 4.0. Terlihat pada beberapa bulan belakangan ini semenjak pemerintah memutuskan untuk melakukan pembelajaran secara online, semua jenis kegiatan tersebut tidak terlepas dari penggunaan koneksi internet (Karim, 2020). Seperti halnya yang dikemukakan oleh Indrawati, (2020) dimana pembelajaran yang tadinya dilakukan secara tatap muka atau secara langsung berganti menjadi pembelajaran secara daring atau pembelajaran jarak jauh.

Segala aktivitas pembelajaran dilakukan secara online termasuk kegiatan praktikum. Media virtual laboratorium merupakan media yang dapat menjadi solusi atau alternative yang dapat digunakan dalam kegaitan praktikum. Virtual laboratorium adalah pratikum yang menggunakan simulasi untuk menampilkan proses 
eksperimen. Virtual laboratorium juga dapat menjadikan mahasiswa untuk mengasah beberapa keterampilan diantaranya dapat melakukan pemecahan masalah secara ilmiah, menguasai suatu konsep, membentuk berpikir kreatif serta dapat memperbaharui kemampuan di bidang Information and Communication Technology (ICT) tanpa mengabaikan pengetahuan mengenai laboratorium (Hermansyah et al., 2015).

Beberapa ilmuan khususnya dibidang kimia melakukan pengembangan media virtual laboratorium yang dapat digunakan dalam pembelajaran kimia diantaranya IONiC-VIPEr yaitu sebuah pengajaran laboratorium kimia anorganik berbasis website sebagai solusi dalam pembelajaran jarak jauh yang dikembangkan oleh (Nataro \& Johnson, 2020). VCLs atau virtual chemistry laboratories adalah pengembangan aplikasi masa depan dengan fitur yang lebih umum, realistis, dan fleksibel dalam pengajaran kimia, baik ditingkat sekolah atau tingkat universitas yang dilakukan oleh (Ali \& Ullah, 2020) sedangkan pengembangan Virtual Labs berbasis website untuk pengajaran kimia umum dilakukan untuk melibatkan siswa atau mahasiswa dalam pemecahan masalah yang lebih otentik oleh (Yaron et al., 2010).

Virtual Labs atau Virtual chemistry laboratorium kemudian disingkat menjadi VChemLab, merupakan aplikasi pembelajaran kimia dari website ChemCollective. Namun, aplikasi VChemLab tersebut dapat digunakan secara offline dan online. Jika memilih offline, maka aplikasi yang tersedia adalah aplikasi dalam bentuk portable dengan format (.rar), sehingga tidak perlu dilakukan instalisasi terlebih dahulu. Selain itu, pada aplikasi VChemLab terdapat beberapa materi kimia diantaranya molaritas dan densitas, Stoikiometri, Analisis Kuantitatif, kesetimbangan Kimia, Padatan dan Kelarutan, Termokimia, Asam dan Basa dan Redoks. Simulasi online dari Virtual chemistry laboratorium (VChemLab) ini dirancang untuk membantu siswa atau mahasiswa menghubungkan perhitungan, perubahan dan teori sesuai dengan kegiatan laboratorium nyata. Virtual chemistry laboratorium (VChemLab) juga memungkinkan mahasiswa untuk memilih ratusan reagen/bahan standar dan memanipulasinya yang menyerupai kegiatan prakttikum di laboratorium nyata (Yaron et al., 2010).

VChemLab merupakan media virtual laboratorium yang dapat menjadi solusi atau alternatif yang dapat digunakan dalam kegiatan praktikum, dimana kegiatan praktikum sangat erat kaitanya dengan metode ilmiah. Sesuai yang dikemukakan oleh (Suryaningsih, 2017), bahwa untuk memecahkan suatu persoalan secara sistematis, baik persoalan dalam kegiatan pembelajaran dalam kelas ataupun dalam laboratorium yang dilakukan secara langsung maupun virtual (melalui pembelajaran online) dibutuhkan penerapan metode-metode ilmiah. (Muliana et al., 2019; Ulfa, 2016) mengemukakan bahwa kegiatan-kegiatan termasuk kegiatan praktikum yang dilakukan menggunakan metode ilmiah dapat membentuk sikap ilmiah mahasiswa.

Pengamatan peneliti terhadap keadaan di lapangan mengenai sikap ilmiah mahasiswa program studi pendidikan kimia Fakultas Keguruan dan Ilmu Pendidikan Universitas Sembilanbelas November Kolaka masih perlu dioptimalkan dan diberdayakan. Ini dibuktikan dengan rendahnya kemampuan mahasiswa dalam memecahkan masalah yang diberikan baik dalam kegiatan pembelajaran dalam kelas maupun dalam kegiatan praktikum di laboratorium. Dimana, mahasiswa di prodi pendidikan kimia merupakan calon guru kimia yang harus memiliki kemampuan ilmiah agar nantinya siswa yang dibina dapat memiliki sikap ilmiah.

Berdasarkan uraian yang telah dikemukakan di atas, maka sikap ilmiah merupakan sikap yang sangat penting dimiliki oleh mahasiswa dalam mengikuti setiap proses pembelajaran. Dengan demikian, dipandang perlu untuk melakukan upaya meningkatkan sikap ilmiah mahasiswa melalui penggunaan VChemLab sebagai alternatif media praktikum virtual pada mata kuliah kimia dasar lanjut.

\section{Metode}

Metode yang digunakan pada penelitian ini adalah metode Pre-experiment dengan desain One group pretest-postest yaitu jenis desain penelitian yang dilakukan pretest terlebih dahulu kemudian diberikan perlakukan sehingga capaian yang diinginkan dalam penelitian ini lebih dapat dipercaya. Hal tersebut disebabkan, karena kondisi sebelum diterapkan dan setelah diterapkan media pembelajaran VChemLab dapat dibandingkan (Emzir, 2010). Tabel 1 berikut ini memberikan gambaran mengenai desain penelitian yang digunakan :

Tabel 1. Desain Penelitian One Group Pretest-Postest Design $\mathrm{O}$ $\mathrm{X}$ $\mathrm{O}$ Prettest Perlakuan Posttest 
Keterangan:

X : Penerapan media VChemLab

O : Sikap Ilmiah Awal dan Akhir

Mahasiswa Program Studi Pendidikan Kimia Universitas Sembilanbelas November Kolaka merupakan Populasi dalam penelitian ini. Penelitian ini menggunakan subjek sebanyak 2 kelas yaitu kelas A dan Kelas B, dimana kedua kelasa tersebut berasal dari mahasiswa yang memprogram mata kuliah praktikum kimia dasar lanjut. Kedua kelas diberikan perlakuaan yang sama yaitu menggunakan VChemLab pada kegiatan praktikum. Kelas A terdiri dari 20 mahasiswa sebagai kelas ujicoba dan Kelas B terdiri dari 20 mahasiswa sebagai kelas tiruan untuk memperkuat dan memperoleh capaian penelitian yang akurat. Alasan dalam pengambilan sampel yaitu kedua kelas memiliki kemampuan yang hampir sama, sehingga digunakan teknik purposive sampling (Hariyanto, 2019).

Data hasil penelitian diperoleh menggunakan teknik pengumpulan data melalui penggunaan instrumen yang terdiri dari skala sikap ilmiah dan angket respon mahasiswa. Sikap ilmiah yang dimaksud dalam penelitian ini adalah sikap ilmiah yang muncul dari hasil kegiatan praktikum kimia dasar lanjut menggunakan VChemLab. Indikator sikap ilmiah pada penelitian ini diadopsi dari (Anwar, 2009; Asriyadin, Yulianci, Kaniawati, et al., 2021) meliputi: rasa ingin tahu, menjadi skeptis atau tidak mudah percaya, mengutamakan bukti, teliti dan berpikir kritis.

Pengukuran Sikap Ilmiah menggunakan sebuah skala yang diberikan sebelum dan sesudah kegiatan praktikum virtual menggunakan VChemLab dilakukan yang bertujuan untuk mengetahui indikator sikap ilmiah yang muncul dari setiap mahasiswa. Skala sikap yang diberikan terdiri dari pernyataan-pernyataan yang nantinya akan diisi oleh subjek penelitian, apakah pernyataan itu diterima atau tidak diterima dengan rentang nilai tertentu. Sehingga, pernyataan yang diberikan pada lembar angket terbagi menjadi pernyataan positif dan negatif (Hunaepei, 2016). Skala yang digunakan pada lembar angket mengacu ada skala likert dengan berbagai pilihan, diantaranya sangat setuju, setuju, tidak setuju dan sangat tidak setuju. Yang kemudian disingkat menjadi SS-STS-STS dengan bobot nilai 4-3-2-1 untuk pernyataan positif sendangkan bobot nilai 1-2-3-4 untuk pernyataan negatif (Siregar, 2014).

Selanjutnya digunakan analisis data gain skor untuk mengetahui apakah ada peningkatan sikap ilmiah mahasiswa, sebelum dan sesudah kegiatan praktikum virtual menggunakan VChemLab. Kemudian, data dari Skala sikap ilmiah tersebut digunakan sebagai data untuk uji homogenitas dan normalitas sebagai uji prasyarat, setelah itu dilakukan Uji-t Paired Samples sebagai uji Hipotesis menggunakan bantuan aplikasi IMB SPSS Statistics 26.

\section{Hasil dan Pembahasan}

Data sikap ilmiah mahasiswa kelas A dan kelas B diperoleh dari selisih skor skala sikap akhir dan awal selama praktikum mata kuliah kimia dasar lanjut menggunakan VChemLab. Data sikap ilmiah mahasiswa disajikan pada Tabel 2:

Tabel 2. Nilai dan N-Gain Sikap Ilmiah Mahasiswa

\begin{tabular}{cccccc}
\hline Kelas & N & Sikap Awal & Sikap Akhir & N-Gain & Kategori \\
\hline Kelas A & 20 & 2.37 & 3.05 & 0.42 & Sedang \\
Kelas B & 20 & 2.33 & 3.03 & 0.42 & Sedang \\
\hline
\end{tabular}

Data pada Tabel 2, memberikan gambaran hasil dari sikap ilmiah mahasiswa pada masing-masing kelas sampel yang dapat dilihat berdasarkan perolehan nilai N-Gain dan kategori nilai N-Gain menurut (Meltzer, 2002). Peningkatan sikap ilmiah mahasiswa setalah menggunakan VChemLab dalam kegiatan praktikum materi kimia dasar lanjut mengalami peningkatan dalam kategori sedang. Peningkatan sikap ilmiah mahasiswa yang sedang ini berkaitan dengan kegiatan praktikum dilaksanakan dengan pembelajaran jarak jauh (PJJ), dimana mahasiswa melakukan praktikum ditempat tinggal masing-masing yang di pantau dengan aplikasi zoom meeting. Namun, beberapa mahasiswa mengalami kendala jaringan sehingga sering keluar masuk dari room zoom meeting, sebagaimana yang dikemukan oleh Indrawati (2020) bahwa adanya kendala internet diberbagai daerah khusunya didaerah pedesaan, maka pembelajaran online yang dilakukan kurang optimal. Maka dari itu, 
beberapa mahasiswa dalam kegiatan praktikum virtual menggunkan VChemLab tidak dapat dipantau dengan baik.

Selain itu, Peningkatan sikap ilmiah mahasiswa kategori sedang ini berkaitan dengan terbatasnya waktu pelaksanaan, dimana kegiatan praktikum kimia dasar lanjut menggunakan VChemLab terdiri dari 6 judul percobaan diantaranya pembuatan dan pengenceran larutan, larutan penyangga, Titrasi Asam Basa, Kelarutan, Hukum Hess dan Reaksi Redoks yang dilakukan pada 3 kali pertemuan. Setiap pertemuan dilakukan dua judul percobaan dalam waktu 4 x 50 menit. Terbatasnya waktu pelaksanaan kegiatan praktikum menggunakan VChemLab mengharuskan mahasiswa untuk mengkaji dan memahami sendiri penggunaan aplikasi dan penuntun praktikum yang diberikan dengan cepat. Sedangkan, Azwar (2011) mengatakan bahwa pembentukan sikap ilmiah seseorang membutuhkan waktu yang lama karena merupakan hal yang kompleks, dinamis dan melibatkan interaksi yang lama antar faktor pendukungnya. Dari pernyataan tersebut, dapat ditarik kesimpulan bahwa untuk menanamkan sikap ilmiah pada mahasiswa tidak cukup hanya dengan satu atau dua kali pertemuan saja atau dengan kata lain dalam waktu yang relative singkat, tetapi harus selalu diterapkan disetiap pembelajaran yang dapat membetuk sikap ilmiah secara berkesinambungan atau konsisten dan pengulangan kegiatan praktikum virtual baik menggunakan VChemLab atau media lainnya.

Setiap kegiatan praktikum atau setiap pertemuan masing-masing mahasiswa diminta mengumpulkan laporan sementara, dimana dalam laporan sementara terdiri dari jawaban pertanyaan dan kesimpulan terkait kegiatan praktikum. Sehingga, peningkatan sikap ilmiah yang terjadi pada kategori sedang disebabkan dari tahapan-tahapan praktikum virtual tersebut. Tahapan yang dilakukan yaitu dapat memberikan ruang kepada mahasiswa untuk terlibat secara langsung, dengan demikian mahasiswa dapat menyalurkan rasa ingin tahu, berpikir kritis, teliti dengan mengutamakan bukti dan sikap tidak mudah percaya (skeptis). Hasil tersebut sesuai yang dikemukakan oleh Anwar (2009) bahwa sikap ilmiah mengarah pada sikap terhadap sains yang dapat diebtnuk melalui lingkungan dan faktor personal dari lingkungan, perilaku, serta proses kognitif, integrase dan konsistensi.

Penelitian ini menggunakan lima indikator untuk mengukur nilai sikap ilmiah mahasiswa yaitu rasa ingin tahu, menjadi skeptis atau tidak mudah percaya, mengutamakan bukti, teliti dan berpikir kritis (Anwar, 2009). Indikator sikap ilmiah terdiri dari 20 butir pernyataan dengan menggunakan skala likert. Hasil dari setiap indikator Sikap Ilmiah mahaiswa kelas A ditunjukkan pada Gambar 1 berikut:

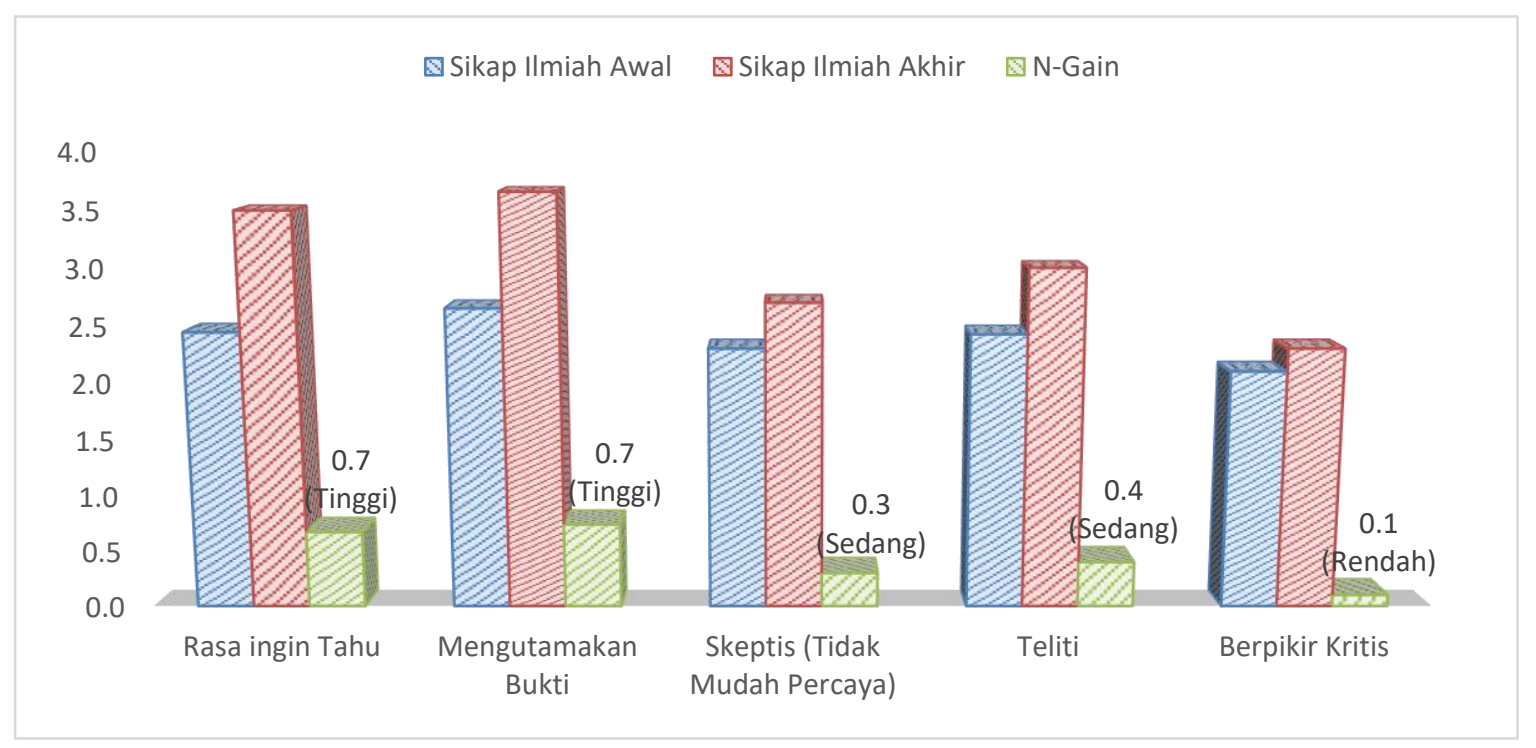

Gambar 1. Analisis Indikator Sikap Ilmiah Mahasiswa Kelas A

Pada Gambar 1, menunjukkan bahwa seluruh aspek sikap ilmiah mahasiswa pada kelas A mata kuliah praktikum kimia dasar lanjut mengalami peningkatan setelah melakukan praktikum menggunakan VChemLab. Sedangkan, Sikap Ilmiah mahasiswa pada kelas B untuk setiap indikator ditunjukkan pada Gambar 2 berikut ini: 


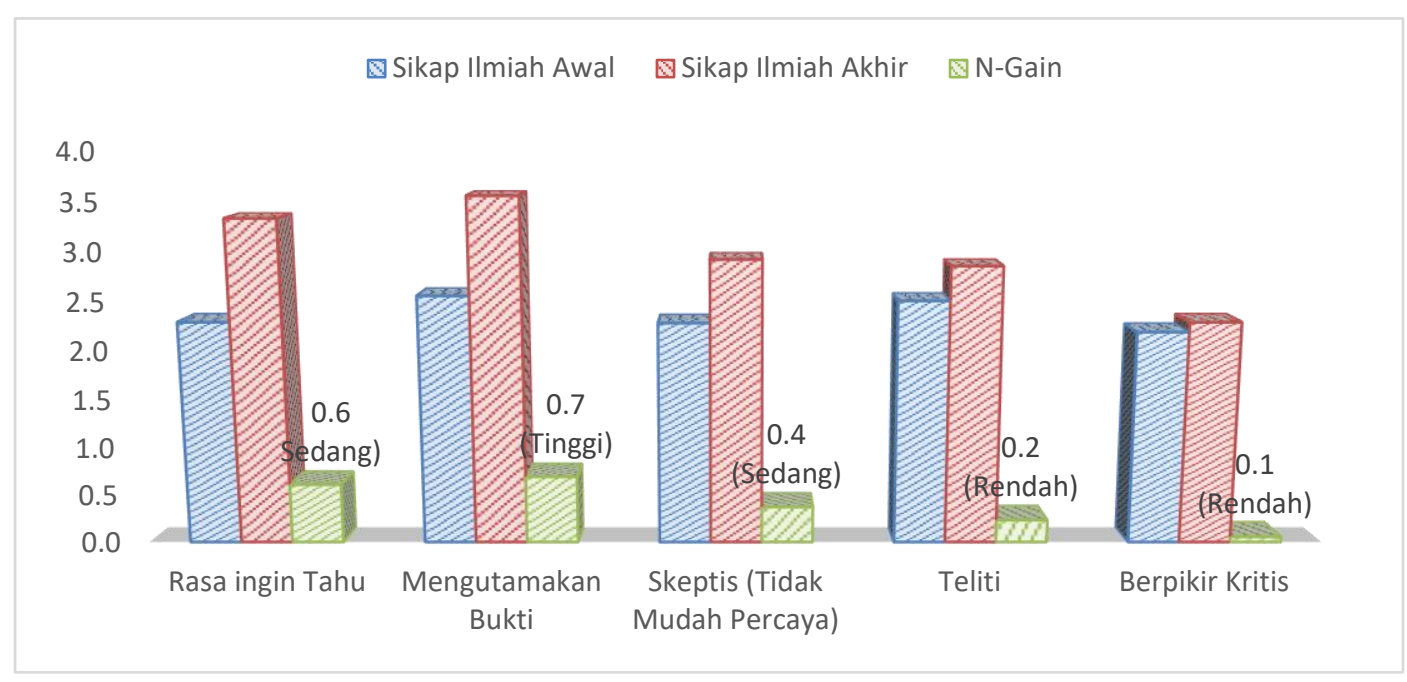

Gambar 2. Analisis Indikator Sikap Ilmiah Mahasiswa Kelas B

Seperti halnya pada kelas A, Gambar 2 menunjukkan bahwa seluruh aspek sikap ilmiah mahasiswa pada kelas B mata kuliah praktikum kimia dasar lanjut mengalami peningkatan setelah melakukan praktikum menggunakan VChemLab.

Hasil setiap analisis Indikator sikap ilmiah, secara lebih terperinci akan diuraikan berikut ini:

\section{a. Rasa Ingin Tahu}

Indikator rasa ingin tahu dengan perolehan skor N-Gain pada kelas A yaitu kategori tinggi sedangkan kelas B kategori sedang, peningkatan ini disebabkan karena sebelum praktikum dimulai mahasiswa diminta untuk menjawab beberapa pertanyaan yang merupakan kunci dalam melakukan prosedur kerja. Penggunaan VChemLab pada mata kuliah praktikum kimia dasar lanjut merupakan pertama kalinya digunakan oleh mahasiswa prodi pendidikan kimia. Sehingga, dapat menumbuhkan sikap antusias dan rasa penasaran serta rasa ingin tahu mahasiswa. Hasil ini sesuai dengan respon mahasiswa dalam angket yang menyatakan bahwa mahasiswa antusias melakukan praktikum menggunakan VchemLab dan menikmati setiap prosedur kerja pada kegiatan praktikum menggunakan media VchemLab. Hal ini sesuai pernyataan Emda (2017) mengatakan bahwa untuk membangkitkan motivasi belajar dan mendorong rasa ingin tahu dapat dilakukan melalui kegiatan eksperimen atau praktikum yang dapat menunjang mahasiswa untuk menemukan pengetahuan melalui eksplorasi.

\section{b. Mengutamakan Bukti}

Aspek mengutamakan bukti dengan nilai N-Gain kelas A dan kelas B adalah kategori tinggi. Aspek tersebut dapat meningkat karena dalam pelaksanaan kegiatan praktikum virtual menggunakan media VChemLab, mahasiswa dibina untuk melakukan analisis dan pembuktian terhadap teori terkait prinsip pembuatan larutan, larutan penyangga, titrasi Asam Basa, Kelarutan, Hukum Hess dan Reaksi Redoks. Dari kegiatan tersebut, dapat menempa mahasiswa untuk membentuk sikap mengutamakan bukti, karena akan mengulang-ulang kegiatan praktikum jika terjadi kesalahan tanpa khwatir akan keterbatasan bahan dan kerusakan alat praktikum. Hal ini sesuai pendapat Farreira dalam Nirwana (2016) bahwa kegiatan praktikum virtual dapat meningkatkan kualitas eksperima, dimana siswa atau mahasiswa dapat mengulang praktikum untuk memperjelas keraguan dalam pengukuran dan pengamatan. Sedangkan menurut (Rohmah et al., 2019) virtual laboratory mampu meningkatkan aktifitas dan keterlibatan siswa atau mahasiswa dalam memperoleh pengetahuan dan keterampilan.

\section{c. Skeptis atau Tidak Mudah Percaya}

Aspek skeptis atau tidak mudah percaya dengan nilai N-Gain kelas A dan kelas B adalah kategori sedang. Meningkatnya aspek skeptis atau tidak mudah percaya pada kategori sedang, disebabkan karena fitur aplikasi VChemLab masih dalam 3D sehingga perubahan-perubahan yang terjadi tidak telihat secara jelas, misalnya proses titrasi tidak terlihat tetesan larutan dari buret ke gelas Erlenmeyer. Berdasarkan angket skala sikap, sebagian mahasiswa lebih percaya pada data yang diperoleh dengan praktikum langsung dibandingkan data dari 
praktikum menggunakan VChemLab. Hal tersebut sesuai dengan Hermansyah et al. (2015) yang mengemukakan bahwa praktikum virtual menggunakan media virtual laboratorium dengan aplikasi tertentu tidak dapat menggantikan fungsi dari laboratorium secara real. Pendapat yang sama juga dikemukakan oleh Serafin \& Chabra (2020), dimana hasil pembelajaran laboratorium virtual tersebut tidak sepenuhnya menggantikan pengalaman praktik langsung di laboratorium. Namun, dari penggunaan VchemLab sebagai alternative media pada praktikum virtual setidaknya membuat mahasiswa dapat melihat fenomena sains secara lebih jelas dibandingkan hanya membaca refrensi, penjelasan dosen atau melaui penugasan pada kegiatan praktikum virtual.

d. Teliti

Aspek teliti dengan nilai N-Gain kelas A kategori sedang sedangkan kelas B kategori rendah. Meningkatnya aspek teliti pada kategori sedang dan rendah, disebabkan karena sebelumnya mahasiswa belum pernah melakukan praktikum secara virtual menggunakan VChemLab. Hal ini, terlihat pada pertemuan pertama dalam melakukan kegiatan praktikum, beberapa mahasiswa kebingungan mengenali ikon peralatan dan penggunaan menu-menu pada aplikasi VchemLab dalam melakukan tahap demi tahap kegiatan praktikum. Hal tersebut disebabkan, karena mahasiswa tidak membaca prosedur kerja dengan teliti pada penuntun praktikum yang membuat praktikum dilakukan berulang-ulang kali. Hal ini didukung oleh Supriyadi (2018) yang telah melakukan peneitian terhadap bahwa kegiatan praktikum virtual akan optimal jika mahasiswa terampil dalam mengoperasikan fitur-fitur praktikum virtual dan pendapat McMaster dalam (Handayani et al., 2018) bahwa kemudahan penggunaan menu pada simulasi komputer seperti pada program praktikum virtual membuat kegiatan praktikum dapat dilakukan berulang kali yang menunjukkan bahwa ketelitian siswa atau mahasiswa rendah.

\section{e. Berpikir Kritis}

Aspek berpikir kritis dengan nilai N-Gain kelas A dan kelas B adalah kategori rendah. Penggunaan VChamLab dapat memfasilitasi mahasiswa untuk bertanya dan menyelesaikan masalah yang diberikan pada penuntun praktikum tentang materi kimia dasar. Hal ini sejalan dengan pendapat (Asriyadin, Yulianci, Adiansha, et al., 2021; Rahayu, 2020) bahwa seseorang akan memiliki kemampuan yang baik ketika sesorang tersebut terbiasa untuk bertanya sehingga kemampuan berpikir kritisnya akan terbentuk. Namun, berdasarkan laporan sementara yang diberikan, terlihat beberapa mahasiswa yang belum mampu menarik kesimpulan dengan baik. Sebagaimana pendapat yang dikemukan oleh (Cahyana et al., 2018; Yulianci et al., 2021) dimana keterampilan berpikir kritis akan terbentuk dilihat dari beberapa indikator salah satunya yaitu ketepatan dalam menyimpulkan untuk memperjelas solusi masalah. Hal ini juga terlihat pada angket respon yang diisi oleh mahasiswa dimana aspek berpikir kritis hanya memperoleh $45 \%$ setuju.

Uji Prasyarat yang digunakan adalah uji normalitas dan homogenitas yang bertujuan untuk mengetahui data yang diperoleh berdistribusi normal atau tidak berdistribusi normal, serta data yang diperoleh adalah varians yang sama atau tidak sama. Hasil uji normalitas dan homogenitas terhadap sikap ilmiah mahasiswa kelas A dan kelas B ditunjukkan pada Tabel 3 berikut ini:

Tabel 3. Uji Prasyarat Sikap Ilmiah Mahasiswa Kelas A dan B

\begin{tabular}{clccc}
\hline Uji Prasyarat & \multicolumn{1}{c}{ Data } & $\begin{array}{c}\text { Sig. (2- } \\
\text { tailed) }\end{array}$ & $\begin{array}{c}\text { Nilai Sig. Tabel } \\
\text { Nilai } \boldsymbol{\alpha}(\mathbf{0 , 0 5 )}\end{array}$ & Kesimpulan \\
\hline Uji Normalitas & Sikap Ilmiah Awal Kelas A & 0.757 & $0.757>0.05$ & Distribusi Normal \\
& Sikap Ilmiah Akhir Kelas A & 0.044 & $0.044>0.05$ & \\
& Sikap Ilmiah Awal Kelas B & 0.087 & $0.087>0.05$ & \\
& Sikap Ilmiah Akhir Kelas B & 0.072 & $0.072>0.05$ & \\
Uji Homogenitas & Sikap Ilmiah Kelas A & 0.704 & $0.704>0.05$ & Distribusi Homogen \\
& Sikap Ilmiah Kelas B & 0.601 & $0.601>0.05$ & \\
\hline
\end{tabular}

Pada Tabel 3, diperoleh gambaran mengenai nilai sig dari sikap ilmiah mahasiswa kelas A dan kelas B pada uji prasyarat yaitu hasilnya lebih tinggi dari pada nilai $\alpha(0,05)$. Pengambilan keputusan pada uji prasyarat menurut Emzir (2010) dapat dinyatakan bahwa secara keseluruhan data yang diperolah bersifat normal dan bersifat homogen. Sehubungan hasil analisis uji normalitas dan uji homogenitas terpenuhi, maka selanjutnya dilakukan uji t Paired-Sample untuk pengujian hipotesis penelitian yang digambarkan pada Tabel 4 berikut ini: 
Tabel 4. Uji t Paired-Sample Sikap Ilmiah Mahasiswa Kelas A dan B

\begin{tabular}{cccc}
\hline Data & Sig. & Sig. $>\boldsymbol{\alpha}$ atau Sig. $<\boldsymbol{\alpha}$ & Kesimpulan \\
\hline Skala Sikap Ilmiah Kelas A & 0.000 & $0.000<\alpha$ & Ada peningkatan signifikan \\
Skala Sikap Ilmiah Kelas B & 0.000 & $0.000<\alpha$ & Ada peningkatan signifikan \\
\hline
\end{tabular}

Berdasarkan Tabel 4, menunjukkan data hasil uji t Paired-Sample yang diperoleh nilai Sig.(2-tailed) 0,00< $\alpha$ $(0,05)$ berdasarkan pengambilan keputusan pada uji t Paired-Sample t. Sehingga, $\mathrm{H}_{0}$ ditolak dan $\mathrm{H}_{1}$ diterima yang artinya kegiatan praktikum menggunakan VChemLab mata kuliah praktikum kimia dasar lanjut pada kelas A dan kelas B mengalami peningkatan Sikap Ilmiah mahasiswa.

Berdasarkan hasil analisis uji hipotesis pada kelas A dan kelas B, maka dapat diketahui bahwa penggunaan VChemLab sebagai alternative media pada kegiatan praktikum virtual dapat meningkatakan sikap ilmiah mahasiswa sedangkan berdasarkan hasil angket respon mahasiswa menunjukkan bahwa penggunaan VChemLab pada praktikum virtual sangat baik untuk membantu mahasiswa dalam mengembangkan sikap ilmiahnya. Proses pembelajaran berbasis praktikum virtual yang dilakukan dapat memberikan kesempatan kepada mahasiswa untuk mengembangkan sikap ilmiah mereka, seperti rasa ingin tahu, ketelitian, skeptis, teltit, dan berpikir kritis. Sebagaimana yang dikemukakan oleh Anwar (2009), bahwa salah satu sikap yang harus dimikili seorang ilmuan adalah sikap ilmiah, sehingga jika dihadapkan pada suatu masalah atau persoalan yang menggunakan metode ilmiah tidak akan mengalami suatu kesulitan.

\section{Simpulan}

VChemLab adalah media yang dapat dijadikan sebagai alternatif media ditengah Pandemic Covid19 pada kegiatan praktikum virtual yang dapat meningkatkan sikap ilmiah mahasiswa khusunya pada mata kuliah praktikum kimia dasar lanjut. Sikap ilmiah mahasiswa meningkat secara signifikan, namun tergolong kategori sedang. Proses pembentukan sikap membutuhkan waktu yang lama, sedangkan praktikum menggunakan VChemLab pada materi kimia dasar lanjut dilakukan dalam waktu yang terbatas serta VChemLab merupakan media yang pertama kali digunakan dalam kegiatan praktikum kimia dasar.

Hasil dari penelitian ini menghasilkan beberapa saran yang dapat dijadikan salah satu referensi untuk penelitian selanjutnya, yaitu dapat melakukan pengembangan penuntun praktikum menggunakan media VChemlab berbasis inkuiri atau berbasis masalah sehingga dapat melatih berpikir kritis mahasiswa dan melakukan perencanaan waktu saat pelaksanaan praktikum, sehingga praktikum dapat terselesaikan dengan baik, misalnya melakukan satu judul percobaan pada satu pertemuan juga.

\section{Daftar Pustaka}

Ali, N., \& Ullah, S. (2020). Review to Analyze and Compare Virtual Chemistry Laboratories for Their Use in Education. Journal of Chemical Education, 97(10), 3563-3574. https://doi.org/10.1021/acs.jchemed.0c00185

Anwar, H. (2009). Penilaian Sikap llmiah dalam Pembelajaran Sains. Jurnalpelangi Iimu, 2(5), 103-113.

Asriyadin, Yulianci, S., Adiansha, A. A., Kaniawati, I., Liliawati, W., \& Muliana. (2021). The development of character and scientific knowledge of students through inquiry-based learning neuroscience approach. Journal of Physics: Conference Series, 1806(1), 12019. https://doi.org/10.1088/1742-6596/1806/1/012019

Asriyadin, Yulianci, S., Kaniawati, I., \& Liliawati, W. (2021). The formation of students' scientific attitudes through the neuroscience-based inquiry model in physics learning. AIP Conference Proceedings, 2330(1), 50028. https://doi.org/10.1063/5.0043348

Azwar, S. (2011). Sikap Manusia: Teori dan Pengukurannya (2nd ed.). Pustaka Pelajar.

Cahyana, U., Fitriani, E., Rianti, R., \& Fauziyah, S. (2018). Analysis of critical thinking skills in chemistry learning by using mobile learning for level x. IOP Conference Series: Materials Science and Engineering, 434(1). https://doi.org/10.1088/1757-899X/434/1/012086

Djumransjah, H. . (2004). Pengantar Filsafat Pendidikan. Bayumedia Publishing. 
Emda, A. (2017). LABORATORIUM SEBAGAI SARANA PEMBELAJARAN KIMIA DALAM MENINGKATKAN PENGETAHUAN DAN KETRAMPILAN KERJA ILMIAH. Lantanida Journal, 5(1), 83. https://doi.org/10.22373/lj.v5i1.2061

Emzir, E. (2010). Metodologi Penelitian Pendidikan: Kuantitatif dan Kualitatif. Rajawali Press.

Handayani, P. H., Tapilouw, F. S., \& Wulan, A. R. (2018). PENINGKATAN SIKAP ILMIAH SISWA MELALUI PEMBELAJARAN BERBASIS PRAKTIKUM VIRTUAL INVERTEBRATA. Jurnal Pelita Pendidikan. https://doi.org/10.24114/jpp.v6i1.9142

Hariyanto, E. (2019). Metode Penelitian ( Metode Pengambilan Sampel Penelitian Survey) (Issue April 2020). Raja Grafindo Persada.

Hermansyah, H., Gunawan, G., \& Herayanti, L. (2015). Pengaruh Penggunaan Laboratorium Virtual Terhadap. Jurnal Pendidikan Fisika Dan Teknologi, I(2), 97-102.

Hunaepei. (2016). Kajian literatur tentang pentingnya sikap ilmiah. Prosiding Seminar Nasional Pusat Kajian Pendidikan Sains Dan Matematika Tahun 2016, November 2017, 548-550.

Indrawati, B. (2020). Tantangan dan Peluang Pendidikan Tinggi Dalam Masa dan Pasca Pandemi Covid-19. Jurnal Kajian Ilmiah, 1(1), 39-48. https://doi.org/10.31599/jki.v1i1.261

Karim, B. A. (2020). Pendidikan Perguruan Tinggi Era 4.0 Dalam Pandemi Covid-19 (Refleksi Sosiologis). Education and Learning Journal, 1(2), 102. https://doi.org/10.33096/eljour.v1i2.54

Meltzer, D. E. (2002). The relationship between mathematics preparation and conceptual learning gains in physics: A possible "hidden variable" in diagnostic pretest scores. American Journal of Physics, 70(12), 1259_ 1268. https://doi.org/10.1119/1.1514215

Muliana, Yusiran, Agustinasari, Asriyadin, Susilawati, E., Sarnita, F., Siswanto, Gumilar, S., Gustina, Erwinsyah, A., Utami, L., Amiruddin, A., \& Syahrir. (2019). Using inductive approach (IA) to enhance students' critical thinking (CT) skills. Journal of Physics: Conference Series, 1280, 52035. https://doi.org/10.1088/1742-6596/1280/5/052035

Nastiti, F., \& Abdu, A. (2020). Kajian: Kesiapan Pendidikan Indonesia Menghadapi Era Society 5.0. Edcomtech Jurnal Kajian Teknologi Pendidikan, 5(1), 61-66. https://doi.org/10.17977/um039v5i12020p061

Nataro, C., \& Johnson, A. R. (2020). A Community Springs to Action to Enable Virtual Laboratory Instruction. Journal of Chemical Education, 97(9), 3033-3037. https://doi.org/10.1021/acs.jchemed.0c00526

Nirwana, R. R. (2016). Pemanfaatan Laboratorium Virtual Dan E-Reference Dalam Proses Pembelajaran Dan Penelitian Ilmu Kimia. Phenomenon: Jurnal Pendidikan MIPA, 1(1), 115. https://doi.org/10.21580/phen.2011.1.1.451

Rahayu, A. (2020). Analisis Keterampilan Proses Sains Mahasiswa pada Praktikum Dasar-Dasar Kimia Analitik. Dalton: Jurnal Pendidikan Kimia Dan Ilmu Kimia, 3(1), 1-10.

Rohmah, M., Ibnu, S., \& Budiasih, E. (2019). PENGARUH REAL LABORATORY DAN VIRTUAL LABORATORY Banyaknya konsep kimia yang bersifat abstrak yang harus diserap peserta didik dalam waktu relatif terbatas (Suyanti , $2010: 42$ ) dan bersifat sangat konseptual, menuntut peserta didik untuk memahami konse. Teladan, 4(1), 83-95.

Serafin, J. M., \& Chabra, J. (2020). Using a Cooperative Hands-On General Chemistry Laboratory Framework for a Virtual General Chemistry Laboratory. Journal of Chemical Education. https://doi.org/10.1021/acs.jchemed.0c00780

Simarmata, J. (2020). Pendidikan Di Era Revolusi 4.0: Tuntutan, Kompetensi EF Tantangan (1st ed.). Yayasan Kita Menulis.

Siregar, S. (2014). Statistik parametrik untuk penelitian kuantitatif: Dilengkapi dengan perhitunganmanual dan aplikasi SPSS versi 17 (1st ed.). Bumi Aksara.

Supriyadi, S. (2018). Pengaruh Praktikum Virtual Terhadap Sikap Ilmiah Siswa Sma. Biosfer: Jurnal Tadris Biologi, 
8(2), 115-131. https://doi.org/10.24042/biosf.v8i2.2302

Suryaningsih, Y. (2017). Pembelajaran Berbasis Praktikum Sebagai Sarana Siswa untuk Berlatih Menerapkan Keterampilan Proses Sains dalam Materi Biologi. Bio Educatio, 2(2), 279492.

Ulfa, S. W. (2016). Pembelajaran Berbasis Praktikum: Upaya Mengembangkan. Jurnal Pendidikan Islam Dan Teknologi Pendidikan, VI(1), 65-75.

Yaron, D., Karabinos, M., Lange, D., Greeno, J. G., \& Leinhardt, G. (2010). The chemcollective - virtual labs for introductory chemistry courses. Science, 328(5978), 584-585. https://doi.org/10.1126/science.1182435

Yulianci, S., Asriyadin, Nurjumiati, Kaniawati, I., Liliawati, W., \& Muliana. (2021). Preliminary analysis of module development by setting arguments through the application of scientific inquiry models to improve students' scientific attitudes. Journal of Physics: Conference Series, 1806(1), 12021. https://doi.org/10.1088/1742-6596/1806/1/012021 